\title{
FORMULASI SEDIAAN MASKER PEEL OFF DARI EKSTRAK DAUN BELIMBING WULUH (Averrhoa Bilimbi L) MENGGUNAKAN BASIS CARBOPOL 934
}

\author{
Peel-Off Mask Formulation From Bilimbi (Averrhoa Bilimbi L) Leaves Extract Using \\ Carbopol 934
}

\section{Zainuddin*, Sry Widyastuti, Samsidar Usman, Citra Wulan}

Fakultas Farmasi Universitas Indonesia Timur

*Email : zheink88@gmail.com

DOI: https://doi.org/10.32382/mf.v15i2.1262

\begin{abstract}
This research aims to formulate a peel-off mask from bilimbi (Averrhoa bilimbi L) leaf, which contains flavonoids with an antibacterial effect on acne. The leaf extracts were obtained by maceration using 96\% ethanol with the formulation of a Peel Off mask using Carbopol 934 base with extract concentrations of $0 \%, 10.5 \%, 11 \%$, and $12 \%$. It was further tested for physical stability. The results showed that the Peel Off mask from bilimbi leaf extract concentration was $10.5 \%$ and fulfilled all requirements.
\end{abstract}

Keywords: Peel-Off Mask; Bilimbi Leaf Extract (Averrhoa bilimbi L); Carbopol 934

\section{ABSTRAK}

Daun belimbing wuluh (Averrhoa blimbi L) mengandung flavonoid yang diketahui mempunyai efek sebagai antibakteri terhadap bakteri penyebab jerawat yang cocok dikembangkan menjadi Masker Peel Off. Penelitian ini bertujuan untuk memformulasi sediaan masker peel off dari ekstrak daun belimbing wuluh (Averrhoa Bilimbi L) menggunakan basis carbopol 934. Ekstrak Daun belimbing wuluh (Averrhoa Bilimbi L) diperoleh dengan cara maserasi menggunakan etanol 96\% lalu dibuat Masker Peel Off dengan basis Carbopol 934 dengan konsentrasi ekstrak Daun belimbing wuluh (Averrhoa Bilimbi L) 0\%, 10,5\%, $11 \%$ dan $12 \%$ lalu di uji Stabilitas mutu fisiknya. Hasil Penelitian menunjukan Masker Peel Off konsentrasi ekstrak Daun belimbing wuluh (Averrhoa Bilimbi L) konsentrasi 10,5\% memenuhi semua persyaratan .

Kata kunci : Masker Peel Off; Ekstrak Daun Belimbing Wuluh (Averrhoa bilimbi L) ; Carbopol 934

\section{PENDAHULUAN}

Kosmetik adalah sediaan atau paduan bahan yang siap untuk digunakan pada bagian luar badan (epidermis, rambut, kuku, bibir dan organ kelamin bagian luar), gigi dan rongga mulut untuk membersihkan, menambah daya tarik, mengubah penampakan, melindungi supaya tetap dalam keadaan baik, memperbaiki bau badan tetapi tidak dimaksudkan untuk mengobati atau menyembuhkan suatu penyakit (BPOM RI, 2003).

Salah satu kosmetik yang berkembang pesat di masyarakat saat ini adalah masker tradisional. Masker ini dibuat dari sari buah buahan yang memiliki daya pembersih, disamping itu dapat pula berfungsi sebagai penyegar dan pengencang kulit wajah. Pada umumnya masker memiliki sifat menghaluskan dan menyegarkan kulit dapat dengan zat pengencang (Astrigent). Bila dilakukan penambahan minyak atau lemak pada masker dapat membuat kulit menjadi lentur dan lemas (Rostamailis, 2005).

Beberapa masker dirancang untuk menguat atau kering pada wajah, hampir seperti plester, yang lain tetap basah. (Ridwan Fauzi. A dan R.Nurmalina, 2012).Masker peel off merupakan masker gel yang praktis dalam penggunaannya karena setelah kering masker dapat langsung dilepas dan menghilangkan sisasisa kotoran yang menempel pada permukaan kulit wajah. Masker wajah peel off memiliki beberapa manfaat, diantaranya mampu merilekskan otot-otot wajah, membersihkan ,menyegarkan, melembabkan, dan melembutkan kulit wajah (Viera, et al, 2009).

Pemberian sediaan topikal yang tepat dan efektif diharapkan dapat mengurangi dan mencegah infeksi pada kulit. Bentuk sediaan gel 
topikal dipilih karena mempunyai beberapa keuntungan yaitu, nyaman dipakai dan mudah meresap pada kulit, memberi rasa dingin, tidak lengket, dan mudah dicuci dengan air (Syamsuni, H.A, 2007).

Belimbing wuluh sering dijumpai di pekarangan rumah atau dikebun belakang. Dalam penelitian Hengky Setiawan yang berjudul "Optimasi formula gel antiacne ekstrak daun belimbing wuluh (Averrhoa bilimbi L) dengan carbopol 940 sebagai gelling agent dan propilen glikol sebagai humektan" disebutkan bahwa daun belimbing wuluh mengandung flavonoid yang diketahui mempunyai efek sebagai antibakteri terhadap bakteri penyebab jerawat. Efek belimbing wuluh diantaranya dapat menghilangkan jerawat, sebagai antioksidan dan sebagai pelembut wajah. Bagian yang bisa digunakan, yaitu buah, batang, daun dan bunganya (Hariana.A, 2004). Dalam penelitian Oktadoni Saputra dan Nur Anggraini, dengan judul "Khasiat Belimbing Wuluh (Averrhoa blimbi L) terhadap Penyembuhan Acne Vulgaris" menunjukkan bahwa ekstrak daun belimbing wuluh, konsentrasi 10,5\%, 11\%, 12\% adalah steril $0 \mathrm{CFU} / \mathrm{ml}$, dimana tidak dijumpai pertumbuhan bakteri dalam media blood agar atau bakteri yang berkontak dengan bahan coba $100 \%$ mengalami kematian.

Berdasarkan uraian di atas maka dapat di rumuskan masalah apakah ekstrak daun belimbing wuluh (Averrhoa blimbi L) dapat dikembangkan sebagai sediaan masker peel off dan bagaimana kestabilannya ?

Tujuan penelitian ini adalah untuk mengetahui konsentrasi ekstrak daun belimbing wuluh manakah yang dapat dimanfaatkan sebagai sediaan masker peel off yang stabil.

Manfaat dari penelitian ini adalah sebagai sumber referensi masyarakat ataupun mahasiswa tentang penggunaan daun belimbing wuluh (Averrhoa bilimbi L) salah satunya sebagai dasar pembuatan kosmetik yaitu masker,dan sebagai referensi untuk peneliti selanjutnya.

METODE

Jenis penelitian

Jenis penelitian yang dilakukan adalah penelitian eksperimen laboratorium.

\section{Waktu dan Tempat Penelitian}

Penelitian ini telah dilakukan pada tanggal 27 Juli - 6 Agustus 2018 di Laboratorium Tekhnologi Farmasi Universitas Indonesia Timur.

\section{Alat dan Bahan}

Alat yang digunakan antara lain Batang pengaduk, Cawan porselin, Gelas arloji, Gelas kimia, Gelas piala, Gelas ukur, Kertas perkamen, Lumpang porselin, Pembakar spiritus, $\mathrm{pH}$ meter, Stamfer, Timbangan analitik, Sendok tandu, Viskometer (Brookfield), Wadah Masker. Dan bahan-bahan yang dgunakan adalah Aluminium foil, Air suling, Ekstrak daun belimbing wuluh (Averrhoa bilimbi L), Carbomer 940, Etanol 96\%, Gliserin, Metil paraben, PVA dan Trietanolamin.

\section{Penyiapan Bahan Uji}

Bahan uji yang digunakan berupa daun belimbing wuluh (Averrhoa Bilimbi L) yang berasal dari Kecamatan TamalateKota Makassar.

\section{Pengolahan Bahan Uji}

Daun belimbing wuluh (Averrhoa bilimbi L) dibuat simplisia.

\section{Ekstraksi Simplisia}

Simplisia daun belimbing diekstraksi dengan etanol $96 \%$

\section{Formula masker}

Masker peel off dibuat dengan variasi konsentrasi ekstrak daun belimbing wuluh. Komposisi selengkapnya dapat dilihat pada tabel

Tabel 1. Rancangan Formula Masker Peel Off Ekstrak Daun Belimbing Wuluh (Averrhoa bilimbi L) dengan Variasi Konsentrasi

\begin{tabular}{cccccc}
\hline & \multicolumn{3}{c}{ Konsentrasi (\% b/v) } & \multirow{2}{*}{ Kegunaan } \\
\cline { 2 - 5 } & $\begin{array}{c}\text { FI } \\
\text { Kontrol Negatif }\end{array}$ & FII & FIII & FIV & \\
\hline $\begin{array}{c}\text { Ekstrak daun } \\
\text { belimbing wuluh }\end{array}$ & - & $10,5 \%$ & $11 \%$ & $12 \%$ & - \\
\hline Polivinil alcohol & $10 \%$ & $10 \%$ & $10 \%$ & $10 \%$ & $\begin{array}{c}\text { Pembentuk } \\
\text { lapisan } \\
\text { film }\end{array}$ \\
\hline Carbomer 940 & $1 \%$ & & & & $\begin{array}{c}\text { Basis gel } \\
\text { Gliserin }\end{array}$ \\
\hline Trietanolamin & $10 \%$ & $1 \%$ & $1 \%$ & $1 \%$ & $10 \%$ \\
\hline
\end{tabular}




\begin{tabular}{cccccc}
\hline Nipagin & 0,2 & 0,2 & 0,2 & 0,2 & Pengawet \\
\hline Air suling & ad $100 \mathrm{ml}$ & ad $100 \mathrm{mlad} 100 \mathrm{mlad} 100 \mathrm{ml}$ & Pelarut
\end{tabular}

\section{Cara pembuatan : \\ Kontrol Negatif}

Polivinil alkohol ditambahkan aquadest empat kalinya lalu dipanaskan dalam gelas piala, diaduk sampai warnanya bening dan homogen (campuran 1). Panaskan aquadest, larutkan nipagin, tambahkan carbomer 940 aduk hingga membentuk gel dan mengembang dengan baik, lalu masukkan dalam lumpang tambahkan Tea lalu gerus (campuran 2). Masukkan campuran 1 dan 2 kedalam lumpang kemudian ditambahkan gliserin, gerus hingga homogen lalu dibiarkan hingga dingin sampai membentuk basis masker gel peel off.

\section{Ekstrak Belimbing Wuluh 10,5\%)}

Polivinil alkohol ditambahkan aquadest empat kalinya lalu dipanaskan dalam gelas piala, diaduk sampai warnanya bening dan homogen (campuran 1). Panaskan aquadest, larutkan nipagin, tambahkan carbomer 940 aduk hingga membentuk gel dan mengembang dengan baik, lalu masukkan dalam lumpang tambahkan Tea lalu gerus (campuran 2). Masukkan ekstrak belimbing wuluh $10,5 \%$ kedalam lumpang, tetesi dengan etanol $96 \%$ gerus hingga larut, ditambahkan campuran 1 dan campuran 2 ke dalam lumpang lalu gerus, kemudian ditambahkan gliserin gerus hingga homogen lalu dibiarkan hingga dingin sampai membentuk basis masker gel peel off.

Diberi perlakuan yang sama untuk Formula III dan IV dengan konsentrasi ekstrak belimbing wuluh yang berbeda yaitu $11 \%$ (FIII) dan $12 \%$ (FIV).

\section{Penentuan Mutu Fisik Sediaan}

Penentuan fisik sediaan dilakukan terhadap sediaan masker peel off meliputi uji homogenitas, pengamatan organoleptis, pengukuran $\mathrm{pH}$, pengujian daya sebar, pengujian waktu sediaan mengering, dan penentuan viskositas sediaan gel.

a. Pengamatan Organoleptis

Pengamatan organoleptis meliputi bentuk, perubahan warna dan bau dari sediaan masker peel off yang diamati secara visual

b. Uji Homogenitas

Uji homogenitas dilakukan dengan menggunakan objek gelas. Sejumlah tertentu sediaan jika dioleskan pada sekeping kaca atau bahan transparan lain yang cocok, sediaan harus menunjukkan susunan yang homogen dan tidak terlihat adanya butiran kasar (Depkes RI, 1979)

c. Pengukuran $\mathrm{pH}$ Pengukuran $\mathrm{pH}$ dengan menggunakan $\mathrm{pH}$ meter. $\mathrm{pH}$ sediaan gel harus serupa dengan $\mathrm{pH}$ kulit yaitu antara 4,5 dan 6,5 (Anief, M., 2012).

d. Pengujian Daya Sebar Pengujian daya sebar dilakukan untuk mengetahui kecepatan penyebaran gel pada kulit saat dioleskan pada kulit. Sebanyak 1 gram sediaan gel peel off diletakan dengan hati-hati diatas kertas grafik berlapis plastik bening, selanjutnya ditutupi dengan plastik bening lain yang lebih tebal dan digunakan pemberat diatasnya bobot 150 gram dan diukur diameternya setelah 1 menit. Persyaratan daya sebar yaitu antar 5-7 cm (Garg et al., 2002)

e. Pengujian Waktu Sediaan Mengering Pengujian waktu kering dilakukan dengan cara mengoleskan masker peel off ke sebagian area lengan bawah atau di belakang daun telinga dengan tebal kira-kira $1 \mathrm{~mm}$ dan diamati waktu yang diperlukan sediaan untuk mongering, yaitu waktu dari saat mulai dioleskan masker peel off hingga benar-benar terbentuk lapisan yang kering. Persyaratan untuk waktu sediaan mengering yaitu selama 15-30 menit (Slavtcheff, 2000).

f. Pengujian Visikositas

Pengujian viskositas di lakukan dengan menggunakan viscometer (Brookfield). Semua pengujian dan pengukuran pada gel mendapat perlakuan kondisi penyimpanan dipercepat, dimana gel disimpan pada suhu kamar $35^{\circ} \mathrm{C}$ selama 10 hari. Nilai viskositas sediaan gel peel off yang baik yaitu 2000-4000 cps (Garg, et al., 2002)

\section{Pengamatan dan Pengolahan Data}

Pengamatan dan pengolahan data sediaan dilakukan dengan pengujian kestabilan fisik dengan mengamati homogenitas, organoleptis, $\mathrm{pH}$, daya sebar, waktu sediaan mengering, dan viskositas. 
HASIL

Dari hasil penelitian tentang formulasi dan uji stabilitas sediaan masker peel off dari Tabel 2. Hasil Pengamatan Organoleptik ekstrak daun belimbing wuluh (Averrhoa bilimbi L) menggunakan basis carbopol maka diperoleh hasil sebagai berikut :

\begin{tabular}{cccccccc} 
& \multicolumn{6}{c}{ Jenis pemeriksaan } \\
\cline { 2 - 7 } Jenis sediaan & \multicolumn{2}{c}{ Sebelum penyimpanan } & \multicolumn{3}{c}{ Sesudah penyimpanan } \\
\cline { 2 - 7 } & Warna & Bau & Bentuk & Warna & Bau & Bentuk \\
\hline Formula 1 & Bening & $\begin{array}{c}\text { Tidak } \\
\text { berbau }\end{array}$ & Gel & Bening & $\begin{array}{c}\text { Tidak } \\
\text { berbau }\end{array}$ & Gel \\
\hline Formula 2 & $\begin{array}{c}\text { Coklat } \\
\text { muda }\end{array}$ & $\begin{array}{c}\text { Bau khas } \\
\text { ekstrak }\end{array}$ & Gel & $\begin{array}{c}\text { Coklat } \\
\text { muda }\end{array}$ & $\begin{array}{c}\text { Bau khas } \\
\text { ekstrak }\end{array}$ & Gel \\
\hline Formula 3 & $\begin{array}{c}\text { Coklat } \\
\text { tua }\end{array}$ & $\begin{array}{c}\text { Bau khas } \\
\text { ekstrak }\end{array}$ & Gel & Coklat tua & $\begin{array}{c}\text { Bau khas } \\
\text { ekstrak }\end{array}$ & Gel \\
\hline Formula 4 & $\begin{array}{c}\text { Coklat } \\
\text { tua }\end{array}$ & $\begin{array}{c}\text { Bau khas } \\
\text { ekstrak }\end{array}$ & Gel & Coklat tua & $\begin{array}{c}\text { Bau khas } \\
\text { ekstrak }\end{array}$ & Gel
\end{tabular}

Pengamatan organoleptik menunjukkan bahwa masker peel off yang di buat dengan menggunakan basis carbopol dengan variasi konsentrasi ekstrak daun belimbing wuluh sebelum dan sesudah penyimpanan menunjukkan tidak mengalami perubahan bentuk warna dan bau.

1. Uji Kestabilan Fisik

a. Uji Homogenitas

Hasil pemeriksaan homogenitas terhadap sediaan masker peel off ekstrak daun belimbing wuluh menunjukkan bahwa semua sediaan tidak memperlihatkan adanya butirbutir kasar pada saat sediaan dioleskan pada kaca transparan. Hal ini menunjukkan bahwa sediaan yang dibuat memiliki susunan yang homogen.

b. Pengukuran $\mathrm{pH}$

Pengukuran $\mathrm{pH}$ dilakukan dengan menggunakan $\mathrm{pH}$ meter yaitu dilakukan sebelum dan sesudah penyimpanan selama 10 hari, hasil dapat dilihat pada tabel berikut :

Tabel 3. Hasil Pengamatan Uji pH Sediaan

\begin{tabular}{ccc} 
& \multicolumn{2}{c}{ Pengamatan } \\
\cline { 2 - 3 } Formula & $\begin{array}{c}\text { Sebelum } \\
\text { Penyimpanan }\end{array}$ & $\begin{array}{c}\text { Sesudah } \\
\text { Penyimpanan }\end{array}$ \\
\hline $\begin{array}{c}\text { Formula 1 } \\
\text { (Kontrol Negatif) }\end{array}$ & 6,4 & 6,4 \\
\hline $\begin{array}{c}\text { Formula 2 } \\
\text { (Ekstrak 10,5\%) }\end{array}$ & 6,1 & 6,0 \\
\hline $\begin{array}{c}\text { Formula 3 } \\
\text { (Ekstrak 11\%) }\end{array}$ & 5,9 & 5,8 \\
\hline $\begin{array}{c}\text { Formula 4 } \\
\text { (Ekstrak 12\%) }\end{array}$ & 5,7 & 5,6
\end{tabular}

c. Hasil pengamatan waktu sediaan mengering dapat dilihat pada tabel berikut :

Tabel 4. Hasil Pengamatan Waktu Sediaan Mengering

\begin{tabular}{lc}
\multicolumn{1}{c}{ Formula } & $\begin{array}{c}\text { Lama } \\
\text { pengeringan }\end{array}$ \\
\hline Formula 1 (Kontrol negatif) & 25,00 \\
\hline Formula 2 (Ekstrak 10,5\%) & 28,51, \\
\hline Formula 3 (Ekstrak 11\%) & 34,36 \\
\hline Formula 4 (Ekstrak 12\%) & $48,37^{\prime}$
\end{tabular}


d. Hasil pengujian daya sebar yang dilakukan setelah penyimpanan selama 10 hari

Tabel 5. Hasil Pengamatan Pengujian Daya Sebar

\begin{tabular}{ccccc}
\multirow{2}{*}{ Formula } & $\begin{array}{c}\text { Berat } \\
\text { sampel }\end{array}$ & Berat beban & $\begin{array}{c}\text { Sebelum } \\
\text { Penyimpanan }\end{array}$ & $\begin{array}{c}\text { Setelah } \\
\text { Penyimpanan }\end{array}$ \\
\cline { 3 - 5 } & & Sebaran & Sebaran \\
\hline 1 & 1 gram & 150 gram & $5,3 \mathrm{~cm}$ & 6,9 \\
\hline 2 & 1 gram & 150 gram & $4,5 \mathrm{~cm}$ & 5,9 \\
\hline 3 & 1 gram & 150 gram & $4 \mathrm{~cm}$ & 5,2 \\
\hline 4 & 1 gram & 150 gram & $3,5 \mathrm{~cm}$ & 4,6
\end{tabular}

e. Hasil pengamatan Visikositas

Tabel 6. Hasil Pengamatan Visikositas

\begin{tabular}{ccc}
$\begin{array}{c}\text { Formula } \\
\text { Gel }\end{array}$ & $\begin{array}{c}\text { Sebelum } \\
\text { Penyimpanan }\end{array}$ & $\begin{array}{c}\text { Setelah } \\
\text { penyimpanan }\end{array}$ \\
\hline 1 & $2543 \mathrm{cps}$ & $2418 \mathrm{cps}$ \\
\hline 2 & $3161 \mathrm{cps}$ & $2849 \mathrm{cps}$ \\
\hline 3 & $3623 \mathrm{cps}$ & $3242 \mathrm{cps}$ \\
\hline 4 & $5699 \mathrm{cps}$ &
\end{tabular}

\section{PEMBAHASAN}

Pada pembuatan sediaan dari tanaman belimbing wuluh (Averrhoa bilimbi $\mathrm{L}$ ) ini telah dipilih sediaan dalam bentuk gel dengan segala pertimbangan. Dalam prinsipnya bahan pembawa dalam sediaan farmasi disyaratkan untuk tidak mempengaruhi efek bahan aktif, tetapi tidak bisa dipungkiri bahwa pembawa dapat memberi pengaruh pada difusi bahan aktif dari pembawa menuju sisi aksi, serta stabilitas bahan yang tinggi dalam pembawa, yang secara terpisah atau bersamaan dapat menyebabkan sediaan lambat atau tidak memberikan efek.

Begitupun dalam stabilitas fisik sediaan gel sangat tergantung pada jenis dan konsentrasi pembawa (gelling agent) dan konsentrasi ekstrak yang digunakan. Kemampuan bahan pembentuk gel ini dalam memerangkap cairan sangat tergantung dari konsentrasi yang digunakan. Oleh karena itu penentuan formula gel ekstrak tanaman ini dilakukan dengan pengujian stabilitas fisik sediaan gel dengan berbagai kosentrasi ekstrak tanaman. Dengan melakukan uji stabilitas fisik dapat diketahui pengaruh terhadap parameter parameter stabilitas fisik sediaan seperti pengamatan organolepis, visikositas, daya sebar, homogenitas, waktu sediaan mengering, $\mathrm{pH}$.

Hasil pemeriksaan organoleptik menunjukkan bahwa ke empat formula stabil secara fisik karena tidak mengalami perubahan warna, bau sediaan dan konsistensi salah satu indikator perubahan yang mengarah pada ketidakstabilan suatu sediaan adalah terjadinya perubahan bentuk, warna, bau, dan bentuk yang terjadi selama penyimpanan.
Pada uji homogenitas bertujuan untuk mengamati ada atau tidaknya partikel kasar pada sediaan. Pada keempat formula yag di uji memiliki homogenitas yang baik, karena tidak adanya partikel kasar pada sediaan.

Pada pengujian $\mathrm{pH}$, Sediaan masker peel off disimpan pada suhu kamar selama 10 hari, hasil $\mathrm{pH}$ sediaan masker peel off mengalami perubahan $\mathrm{pH}$ selama penyimpanan, dimana di dapatkan $\mathrm{pH}$ sebelum penyimpanan berkisar antara antara 5,7-6,4 dan setelah penyimpanan 5,6-6,4. Dari data yang diperoleh dapat dilihat bahwa semakin banyak jumlah ekstrak daun belimbing wuluh yang ditambahkan maka $\mathrm{pH}$ sediaan semakin menurun atau dengan kata lain pH semakin asam. Hal ini dapat disebabkan karena pH ekstrak daun belimbing wuluh yang asam yaitu 4,6. Semakin alkalis atau semakin asam bahan yang mengenai kulit, semakin sulit kulit untuk menetralisirnya dan kulit dapat menjadi kering, pecah-pecah, sensitif, dan mudah terkena infeksi. Oleh karena itu $\mathrm{pH}$ kosmetika diusahakan sama atau sedekat mungkin dengan $\mathrm{pH}$ fisiologis kulit yaitu antara 4,5-6,5.

Pengujian waktu sediaan mengering dilakukan dengan mengamati waktu yang diperlukan sediaan mengering, yaitu waktu saat dioleskannya masker peel off pada kulit bagian bawah lengan hingga terbentuk lapisan film yang kering. Hasil yang diperoleh menunjukkan bahwa semakin tinggi konsentrasi ekstrak yang diberikan pada sediaan maka waktu yang dibutuhkan sediaan masker peel off untuk mengering semakin meningkat. Pada formula 1 dan 2 menunjukkan waktu mengering antara 
25,00' hingga 29,00' sedangkan pada Formula 3 dan 4 diperoleh waktu mengering antara 34,00' hingga 49,00' dapat disimpulkan bahwa formula 1 dan 2 lebih stabil dan formula 3 dan 4 tidak stabil karena syarat waktu mengering sediaan masker peel off yaitu 15 hingga 30 menit.

Pada hasil pengujian daya sebar dilakukan untuk mengetahui kemampuan menyebar sediaan gel saat dioleskan pada kulit. Dari pengamatan dengan menggunakan analisis grafik, menunjukkan bahwa ke empat formula mengalami daya sebar yang berbeda namun yang menunjukkan angka pergeseran yang lebih besar adalah formula 1 dan yang menunjukkan angka terkecil adalah formula 4 jadi dapat disimpulkan bahwa semakin tinggi konsentrasi ekstrak maka daya sebar sediaan akan berkurang. Penurunan daya sebar terjadi melalui meningkatnya ukuran unit molekul karena mengabsorbsi pelarut hingga cairan tersebut tertahan dan meningkatkan tahanan untuk mengalir dan menyebar.

Uji visikositas dilakukan untuk mengetahui besarnya suatu visikositas dari sediaan, dimana nilai visikositas tersebut menyatakan besarnya tahanan suatu cairan itu mengalir. Pengukuran visikositas dilakukan menggunakan visikometer brokfield dengan menggunakan spindle no 64 dengan kecepatan $100 \mathrm{rpm}$. hasil yang didapatkan bisa dilihat pada tabel no. 6 dan dapat disimpulkan bahwa semakin tinggi konsentrasi ekstrak maka semakin tinggi visikositas suatu sediaan.

\section{KESIMPULAN}

Berdasarkan hasil penelitian yang telah dilakukan terhadap masker peel off dapat disimpulkan bahwa Ekstrak daun belimbing wuluh dengan konsentrasi $10,5 \%$ dapat di formulasikan menjadi masker peel off dengan menggunakan carbopol 934.

\section{DAFTAR PUSTAKA}

Agoes, G., 2009. Teknologi Bahan Alam. Penerbit ITB; Bandung

Anief, M., 2012. Farmaseutika. Gadjah Mada University press; Yogyakarta

Ansel. H.C., 2011. Pengantar Bentuk Sediaan Farmasi Edisi Keempat, Universitas Indonesia; Jakarta

Aulton, M., 1988. Pharmaceutics The Sciens Of Dosage From Design. Curcilliringstone, Ediberd; London
Balsam,E.S., 1975. Cosmetic Science and techNology. New York. USA

Basuki, 2003. Tampil Cantik dengan Perawatan Sendiri, Gramedia Pustaka utama; Jakarta

BPOM RI, 2003. Kosmetik. Keputusan Kepala Badan Pengawas Obat dan Makanan Nomor HK.00.05.4.1745 Tahun 2003 tentang Kosmetik.

Departemen Kesehatan RI, 1995. Farmakope Indonesia Edisi IV. Jakarta

Departemen Kesehatan RI, 2000. Parameter Standar Umum Ekstrak Tumbuhan Obat. Direktorat Jenderal Pengawasan Obat dan Makanan; Bhratara

Dwi karya, 2003. Cara Tuntas Membasmi Jerawat. Kawan pustaka : Jakarta

Elshabrina, 2013. Dahsyatnya Daun Obat Sepanjang Masa. Hal.128-129. Cemerlang Publishing; Yogyakarta.

Garg, A., A. Deepika, S. Garg, and A.K. Sigla. 2002. Spreading of semisolid formuation. Pharmaceutical Tecnology; USA

Harina, H Arief., 2004. Tumbuhan Obat dan Khasiatnya. Penerbit Penebar Swadaya: Jakarta.

Hernowo, B. 2011. Panduan Sukses Bertanam 20 Buah dan Sayur. Hal.23. Cable Book; Klaten

Lachman, dkk. 1994. Teori dan praktek farmasi industri 2 edisi ketiga Universitas Indonesia Press; Jakarta.

Marina, B.S., 2015. Formulasi Masker Peel-Off Ekstrak Buah terong Belanda (Cyphomandra betacea Cav.sendtn.) Sebagai Anti Aging. Fakultas farmasi, Universitas Sumatera Utara; Medan

Rabiatul, Hadawiyah M., 2012. Formulasi Sediaan Gel dari Ekstrak Etanol Buah Belimbing Wuluh (Averrhoa blimbi L) dan Uji Aktivitasnya Terhadap Beberapa Bakteri Penyebab Jerawat.

Ridwan Fauzi.A dan R.Nurmalina, 2012. Merawat Kulit dan Wajah. Penerbit PT Elex Media Komputindo Gramedia; Jakarta. 
Rostamailis, 2005. Penggunaan kosmetik dasar kecantikan dan berbusana yang serasi. Rineka cipta; Jakarta.

Rowe, R.C., P.J. Sheskey, dan M.E. Quinn. 2009. Handbook of Pharmaceutical Press and the American Pharmacist Association. USA.

Slavtcheff, C.S., 2000. Komposisi Kosmetik Untuk masker Kulit Muka. Indonesia Patent 2000 / 0004931.

Syamsuni. H.A., 2007. Ilmu resep. Buku Kedokteran EGC; Jakarta.

Tjitrosoepomo,G., 2013, Taksonomi Tumbuhan. UGM Press; Jogjakarta

Vieira, Rafael Pinto, et al. (2009). Physical and Physicochemical Stability Evaluation of Cosmetic Formulatios Containing Soybean Extract Fermented by Bifidobacterium animals. Brazilian Journal of Pharmaceutical Science vo.45 (3) : 515-525.

(c) (1) (2) 